\title{
КОНЦЕНТРИРОВАНИЕ ИОНОВ МЕТАЛЛОВ В СИСТЕМАХ НА ОСНОВЕ КАТИОННОГО ПАВ ХЛОРИДА АЛКИЛБЕНЗИЛДИМЕТИЛАММОНИЯ Елохов А.M.
}

Пермский государственный национальный исследовательский университет elhalex@yandex.ru

Катионные поверхностно-активные вещества (КПАВ) получили широкое распространение в качестве экстрагентов ионов металлов. Образование расслаивающихся систем возможно при высаливании КПАВ неорганическими солями или кислотами, использовании смесей с анионными ПАВ или солями с гидрофобными анионами. В большинстве случаев определяющим эффектом, обуславливающим появление расслаивания, является образование ионных ассоциатов, гидратирующихся в меньшей степени, чем исходные вещества.

В работе показана возможность применения технического катионного ПАВ катамина АБ $\left(\left[\mathrm{C}_{\mathrm{n}} \mathrm{H}_{2 \mathrm{n}+1} \mathrm{~N}\left(\mathrm{CH}_{3}\right)_{2} \mathrm{CH}_{2} \mathrm{C}_{6} \mathrm{H}_{5}\right] \mathrm{Cl}, \mathrm{n}=10-18, \mathrm{R}_{4} \mathrm{NCl}\right)$ для концентрирования ионов металлов в экстракционных системах различного типа.

Среди неорганических кислот наиболее приемлемыми высаливателями катамина АБ являются азотная и хлорная. Образующиеся нитрат и перхлорат алкилбензилдиметиламмония, вследствие меньшей энергии гидратации аниона в сравнении с хлорид-ионом, имеет ограниченную растворимость в воде. Изучение распределения ряда ионов металлов в системе с азотной кислотой, показало, что таллий (III) извлекается более чем на 90\%, железо (III), иттрий, индий и цинк извлекаются менее чем на 20\%, рост степени извлечения лантана и тория наблюдается при концентрации азотной кислоты более 2 моль/л. Введение хлоридов натрия или калия в концентрации более 0,5 моль/л способствует количественному извлечению таллия по анионообменному механизму, предположительно в виде тетрахлороталлат-иона. При использовании в качестве дополнительного комплексообразующего реагента тиоцианата аммония возможно количественное извлечение тиоцианатных ацидокомплексов цинка, кадмия, кобальта, меди (II) и железа (III). Экстрагируемость ионов металлов при этом уменьшается в ряду: $\mathrm{Zn} \approx \mathrm{Cd}>\mathrm{Co}$ (II) $>\mathrm{Cu}$ (II) $>\mathrm{Fe}$ (III)

Введение сульфосалициловой кислоты или салицилата натрия в растворы катамина АБ приводит к образованию малорастворимых ионных ассоциатов, которые способны концентрировать ионы металлов за счет образования комплексных соединений с салицилати сульфосалицилат-ионами. В оптимальных условиях изучено распределение железа (III), цинка, кобальта и меди (II). Максимальная степень извлечения всех ионов металлов с сульфосалициловой кислотой наблюдается при рН более 10. Немонотонное увеличение степени извлечения ионов металлов в зависимости от $\mathrm{pH}$ равновесной водной фазы свидетельствует о возможности образования комплексных соединений различного состава и, следовательно, отличающейся экстрагируемостью. Для системы с салицилатом натрия величина $\mathrm{pH}$, отвечающая максимальному извлечению металлов, увеличивается ряду $\mathrm{Fe}$ (III) $<\mathrm{Cu}$ (II) $<$ Со $<$ Zn и лежит в интервале 2-9. Система с салицилатом натрия может быть использована для извлечения цинка, меди (II) и железа (III) из слабокислых растворов, а также отделение кобальта от железа (III) при рН 2. Во всех случаях экстракты, содержащие ионы металлов, имеют интенсивную окраску и пригодны для разработки экстракционнофотометрических методик определения их содержания в различных объектах. 